\title{
Polemik Aliran Sosialis Marxisme dalam Gerakan Nasionalisme dan Pembangunan Politik Radikal Melayu, 1925-1948
}

\section{The Polemics of Socialist Marxism in the Malay Nationalist Movement and Radical Political Development, 1925-1948}

\author{
*AHAMAD JAMA' AMIN YANG \\ MOHD SAMSUDIN \\ Fakulti Sains Sosial dan Kemanusiaan, Universiti Kebangsaan Malaysia, 43600 UKM Bangi, \\ Selangor, Malaysia \\ *Corresponding author: alperaqi1978@yahoo.com
}

Published online: 15 September 2017

To cite this article: Yang, A.J.A. and Samsudin, M. 2017. Polemik aliran sosialis Marxisme dalam gerakan nasionalisme dan pembangunan politik radikal Melayu, 1925-1948. KEMANUSIAAN the Asian Journal of Humanities 24(2): 31-58, https://doi.org/10.21315/kajh2017.24.2.2

To link to this article: https://doi.org/10.21315/kajh2017.24.2.2

\begin{abstract}
Abstrak. Sejarah gerakan politik aliran sosialis di Tanah Melayu sering digambarkan mempunyai persamaan dengan fahaman politik komunis. Kemelut pandangan ini secara tidak langsung memberi kesan terhadap kefahaman perkembangan dan perjuangan politik aliran sosialis di Tanah Melayu, terutama yang mengaitkan gerakan radikal nasionalisme dengan pembangunan politik Melayu di Tanah Melayu. Sehubungan itu, makalah ini menumpukan kepada perkembangan ideologi politik aliran sosialis melalui pengaruh Sosialis Marxisme dari Indonesia yang menjadi asas perkembangan aliran sosialis dalam kalangan gerakan aliran kiri nasionalis radikal Melayu dalam meneruskan keberlangsungan politik kelas sepanjang tahun 1925 sehingga tahun 1948. Dengan menggunakan pendekatan Reconstructionist sejarah dan interpretasi hermeunitik, analisis perbincangan dikembangkan berdasarkan penggunaan sumber primer sebagai asas hujah, terutama dokumen British, di samping sumber-sumber sekunder yang lain. Dapatan kajian mendapati pengaruh aliran sosialis berkembang dalam dua bentuk aliran, iaitu Sosialis Marxisme dan Reformis Marxisme melalui PKMM, API, AWAS, PETA dan BATAS. Dalam konteks Tanah Melayu, perkembangan aliran ini secara dasarnya dikerangkakan oleh sudut pandang Alimin dan Tan Malaka yang membentuk fahaman radikal dalam kalangan aktor-aktor politik Melayu dan membezakannya antara komunis Sosialis Marxisme dengan Reformis Marxisme. Makalah ini menterjemahkan satu sisi yang berbeza berdasarkan tafsiran sumber utama itu sendiri dan pendekatan politik moden dalam menjelaskan perkembangan aliran sosialis di Tanah Melayu.
\end{abstract}

Kata kunci dan frasa: sejarah politik, Sosialis Marxisme, Reformis Marxisme, aliran kiri, radikal Melayu 
Abstract. The history of the socialist political movement in Malaya has always been identified as having similarities with the history of the communist political ideology. This misconception has influenced the general understanding of the socialist movement struggles and developments in Malaya, especially those related to the radical movements and the Malay political developments in Malaya. Hence, this article focuses on the development of the socialist political ideology as an influence of the Indonesian Socialist Marxism which became a basis for the socialist ideology development by the left-wing Malay radical nationalist movements in their class political survival from 1925 to 1948. Through the history of Reconstructionist and the hermeneutic interpretation approach, the analysis and discussion is developed based on the primary sources such as the British documents as well as the secondary sources to support the arguments. It is found that the socialist ideological influences developed in two forms, i.e. Socialist Marxism and Reformist Marxism through PKMM, API, AWAS, PETA and BATAS. In its Malayan context, this ideology developed as a result of the framework established by Alimin and Tan Malaka world view who formed a radical ideology among the Malay political actors which is different from the Reformist Marxism. This article highlights a different angle based on the interpretation of the primary sources itself and the modern political approach in describing the historical developments of the socialist ideology in Malaya.

Keywords and phrases: political history, Socialist Marxism, Reformist Marxism, left-wing, Malay radical

\section{Pendahuluan}

Kebangkitan gerakan nasionalisme dan pembangunan politik radikal Melayu banyak dipengaruhi daripada luar, terutama dari Indonesia (Soh 2012; Rustam 2011; Firdaus 1985). Namun begitu, penyerapan pengaruh tersebut sering dikaitkan dengan fahaman komunisme yang menyebabkan gerakan nasionalisme dalam kalangan radikal Melayu dianggap 'sebahagian daripada doktrin komunis'. Pandangan ini mewarnai bentuk perjuangan gerakan nasionalisme Melayu radikal yang mana kerangka perjuangannya dilihat seolah-olah dicaturkan oleh aktor-aktor Marxisme dari Indonesia. Walau bagaimanapun, beberapa tafsiran sejarah perlu dikupas dengan lebih mendalam dalam usaha memahami persoalan ini, terutama yang menyentuh cabang-cabang aliran sosialis di Tanah Melayu bagi membezakan beberapa aspek pemikiran sosialis itu sendiri yang dapat menerangkan secara lebih eksklusif perbandingan antara Sosialis Marxisme ${ }^{1}$ dengan Reformis Marxisme ${ }^{2}$, dan sejauh mana autentik pemikiran sosialis ini mampu mempengaruhi budaya dan pendekatan politik dalam kalangan nasionalisme radikal Melayu pada waktu itu. 


\section{Latar Belakang Pengaruh Sosialis di Tanah Melayu}

Pada tahun 1937, kerajaan British telah mengharamkan penerbitan dan pengedaran majalah Left Book Club di seluruh Britain dan negara-negara di bawah jajahannya. Parti Konservatif yang memerintah Britain ketika itu menganggap penerbitan dan pengedaran majalah tersebut merupakan percubaan dalam mengembangkan pengaruh komunis di negara berkenaan dan negara-negara jajahannya, termasuklah Tanah Melayu. Walau bagaimanapun, perkara ini dinafikan oleh Phoenix Book Company Ltd., syarikat penerbitan yang bertanggungjawab menerbitkan majalah tersebut. Isu ini menjadi perdebatan hangat di Parlimen British pada penghujung tahun 1930-an (CO 273/633). Perdebatan tersebut timbul berikutan kerajaan di bawah Parti Konservatif pada ketika itu tidak mempunyai bukti yang kukuh untuk mengaitkan penerbitan Left Book Club dengan aktiviti komunis dan tuduhan hasutan menentang kerajaan yang memerintah, kecuali isi kandungannya yang dilihat cenderung kepada memartabatkan hak-hak buruh, kesedaran mewujudkan masyarakat yang adil dan seimbang daripada segi pemilikan ekonomi dan kebajikan rakyat. Isi kandungan Left Book Club ini mempunyai persamaan dengan aspirasi fahaman Sosialis Marxisme. Sehubungan itu, pengharaman Left Book Club dilihat lebih kepada tindakan awal yang dilakukan oleh Parti Konservatif dalam usaha membendung pengaruh Sosialis Marxisme dan gerakan komunisme di Britain yang mula berkembang melalui Parti Komunis British dan organisasi-organisasi buruh sekitar tahun 1930-an.

Di Tanah Melayu pula, secara dasarnya kefahaman sejarahwan terhadap perkembangan sosialis masih di bawah kerangka pemikiran William R. Roff. Roff melihat kebangkitan golongan radikal dan intelektual politik Melayu berada dalam lingkungan pemikiran Marxisme. Pandangan Roff ini berdasarkan penelitiannya terhadap ideologi politik Kesatuan Melayu Muda (KMM) pada penghujung tahun 1930-an. Walau bagaimanapun, pada masa yang sama Roff mengakui ideologi Marxisme yang digagaskan KMM ini masih dalam bentuk 'samar-samar' (Roff 2003, 244). Pandangan Roff ini ada persamaannya dengan sumber risikan British yang menyatakan:

Information has been received from a reliable source that the notorious Ibrahim Haji Ya'acob, prominent K.M.M. member and self-confessed Japanese agent, is thinking of returning to Malaya. Feelers have been sent out by him to ascertain the probable consequences. He is at present stated to be a "Major-General of the T.R.I." and very close to the Communist Alimin. (FCO 141/15955) 
Namun, pandangan awal Roff ini masih lagi berbentuk persepsi yang memerlukan penelitian yang lebih mendalam. Secara tidak langsung, ini membuktikan bahawa Roff sendiri tidak mampu secara eksklusifnya untuk memberi satu penjelasan terhadap gagasan politik yang dibawa oleh KMM. Pandangan ini ada kaitannya dengan aspirasi KMM yang berbeza dengan fahaman induk pemikiran Marxisme. KMM lebih cenderung kepada gagasan antipenjajahan berteraskan nilai kemelayuan serantau, manakala Marxisme secara umumnya menekankan kesedaran dan perjuangan kelas dalam konteks keadilan politik tanpa mengira latar belakang kaum dan agama. Dalam pensejarahan moden, tidak ada satu penjelasan akademik yang berani menyatakan permulaan perkembangan ideologi sosialis dalam konteks gerakan nasionalisme dan politik di Tanah Melayu kecuali penulisan Ahmat Adam (2013) dan Cheah Boon Kheng (1992). Sepertimana Roff, keduadua sarjana ini tidak membahaskan secara terperinci dan mendalam perkembangan dan klasifikasi aliran Sosialis Marxisme itu sendiri, tetapi mereka lebih cenderung kepada pemahaman pengaruh komunisme Indonesia di Tanah Melayu. Begitu pun, kajian Ahmat Adam dan Cheah Boon Kheng ini membawa beberapa persoalan yang menyentuh tentang polemik perkembangan komunisme di Tanah Melayu daripada segi ideologi, pendekatan dan strategi politik sama ada mempunyai persamaan mutlak dengan pendekatan Marxisme komunis atau sebaliknya.

Pandangan yang sama juga dilontarkan oleh Stockwell (1979) dan Nabir (1976) yang melihat perkembangan pengaruh Indonesia dalam gerakan kiri Tanah Melayu masih di bawah kerangka komunisme. Kedua-dua pandangan sarjana tersebut tidak jauh bezanya dengan pandangan Roff sepertimana yang dijelaskan sebelum ini. Begitu pun, Stockwell tidak membincangkan secara terperinci bentuk dan elemen Indonesia yang dinyatakannya, tetapi lebih menumpukan interaksi sejarah hubungan serumpun orang Melayu antara dua wilayah tersebut yang memberi impak mendalam terhadap peralihan jiwa nasionalis radikal dari Indonesia ke Tanah Melayu dengan penglibatan langsung ahli Parti Komunis Indonesia (PKI) dalam gerakan buruh dan politik seperti General Labour Union (GLU), Parti Kebangsaan Melayu Malaya (PKMM), Angkatan Pemuda Insaf (API), Angkatan Wanita Sedar (AWAS), Ikatan Pembela Tanah Air (PETA) dan Pemuda Radikal Melayu (PERAM) (Stockwell 1979, 131-137). Malah Stockwell tidak memisahkan keadaan politik dan sudut pandang sosialis di Indonesia pada waktu itu yang berpecah dalam tiga aliran berbeza yang bersandarkan MarxismeLeninisme, Reformis Marxisme dan gerakan sosialis demokrasi yang cenderung kepada sosialis bukan Marxisme.

Stockwell memberi satu tanggapan gerakan radikal aliran kiri Melayu dijanakan secara langsung daripada pengaruh komunis Indonesia melalui peranan Tan Malaka, Alimin, Sutan Djenain dan lain-lain lagi yang berkaitan. Kebergantungan 
Stockwell secara terus mentafsir laporan political intelligence journals dalam memahami sumber British tanpa melihat polemik yang berlaku di Indonesia memberikan satu keadaan yang mana seolah-olah berlakunya 'penyatuan dan persefahaman' dalam kalangan beberapa watak induk sosialis antara Tan Malaka, Sutan Syahir dan Soekarno. Polemik tersebut secara langsung mengembangkan idea nasionalisme dan menyuburkan gerakan antipenjajahan di Tanah Melayu. Jelasnya, kesan ini boleh dilihat melalui peranan Dr. Otoeyo di Singapura yang dirujuk dalam sumber British sebagai ejen Indonesia di Tanah Melayu. Dr. Otoeyo memainkan peranan penting dalam Persatuan Indonesia Merdeka (PIM) dan Himpunan Wanita Indonesia (HIWANI) (FCO 141/15673; FCO 141/15957).

Dalam konteks ini, pengaruh nasionalis Indonesia difahami dan diterapkan secara terus dalam gerakan nasionalisme Melayu tanpa adanya perbezaan kesan yang berlaku di Indonesia pada waktu itu, terutama pergeseran antara Alimin, Tan Malaka, Sutan Syahir dan Soekarno pada pertengahan tahun 1940-an. Sedangkan sejak tahun 1920-an sehingga 1940-an, polemik persaingan aliran sudah mula menular antara kelompok komunis, nasionalis sosialis, reformis Islam dan konservatif nasionalis di Indonesia (Ingleson 2014; Shiraishi 1990; Kahin 1952). Penelitian terhadap perbezaan aliran dan pendekatan politik watak-watak berkenaan secara interpretasi hermeunitik perlu dirungkai terlebih dahulu sebelum melihat pengaruh dan impaknya di Tanah Melayu.

Berbanding Stockwell, Nabir lebih menumpukan kepada reaksi gerakan Il-Ihya (Maahad Il Ihya Assyarif di Gunung Semanggol) terhadap pengaruh komunis dalam PKMM dan kecenderungan parti tersebut yang dikuasai oleh golongan kiri bukan Melayu (Nabir 1976, 158). Justeru, tidak menghairankan perbincangan beliau banyak berkisar kepada kelangsungan politik Melayu dan Islam dalam memastikan gerakan nasionalisme di Tanah Melayu pada waktu itu dipimpin oleh orang Melayu. Walaupun pada masa yang sama wujudnya kerjasama politik antara Melayu dengan bukan Melayu melalui Pusat Tenaga Rakyat (PUTERA) dan All-Malayan Council Joint Action (AMCJA). Bagi memastikan keseimbangan dalam kerjasama tersebut, golongan Il-Ihya menubuhkan Hizbul Muslimin yang dilihat mendapat persetujuan daripada Dr. Burhanuddin al-Helmy khususnya dan PKMM amnya. Kerjasama ini ada kaitannya dengan polisi perkembangan gerakan komunisme antarabangsa pada waktu itu yang menyokong perjuangan nasionalisme dan terlibat secara langsung melalui proksi politik dalam usaha menggulingkan rejim kolonialisme di tanah-tanah jajahan, termasuk di Tanah Melayu. Tujuannya adalah bagi memastikan keberhasilan proksi politik tersebut dan keupayaan gerakan komunisme menyingkirkan kerajaan nasionalis selepas itu (Salleh Lamry 2009, 86). Secara tidak langsung, aliran komunisme di Tanah Melayu lebih bersifat 
mendominasi, berbeza cabang-cabang aliran sosialis itu sendiri, terutama yang cenderung kepada sosialis demokrasi dan Reformis Marxisme.

Bagaimanapun, berdasarkan sumber British yang sama, beberapa asas dan tafsiran boleh dikemukakan kembali dalam melihat pengaruh dan perkembangan aliran sosialis yang cenderung kepada Marxisme di Tanah Melayu pada waktu itu (CO 537/3752; FCO 141/15672). Tafsiran yang berbeza dan berlainan pandangan tentang sosialis dan komunis ini lebih memberi perhatian terhadap mobilisasi politik dalam kalangan elit politik yang baharu, terutama golongan elit bukan tradisional (Rustam 2004, 39). Perkembangan aliran sosialis ini dibahagikan kepada dua bentuk acuan; begitu pun kedua-dua bentuk acuan ini saling berkaitan, terutama yang menghubungkan gagasan Sosialis Marxisme dengan agenda antipenjajahan British. Bentuk pertama adalah aliran pemikiran Sosialis Marxisme dari Indonesia yang dikembangkan dalam kalangan aktor nasionalis Melayu yang beridealiskan kelas dan bersifat nasionalis. Bentuk yang kedua pula adalah perbezaan dalam sudut pandang aliran pemikiran Sosialis Marxisme yang berpusatkan percanggahan pandangan antara Tan Malaka dengan Alimin. Perbezaan ini memberi impak secara tidak langsung kepada bentuk kegiatan radikal Melayu, pengaruh dan hubungannya dengan gerakan komunis sekitar tahun 1940-an dan salah faham umum terhadap aliran sosialis yang dilihat sebelum ini didasari oleh komunisme semata-mata.

\section{Pengaruh Sosialis Marxisme Indonesia di Tanah Melayu Sekitar Tahun 1925 Sehingga 1937}

Bentuk pertama merupakan satu gagasan politik yang dibangun berteraskan reaksi kepada semangat antipenjajahan dalam kalangan orang Melayu marhaen khususnya. Sifat nasionalis Melayu golongan ini pada waktu itu banyak didorongi oleh bentuk pemikiran politik Sosialis Marxisme dari Indonesia, terutama dalam kalangan ahli PKI yang melarikan diri ke Tanah Melayu pada akhir tahun 1920an. Sebelum penubuhan KMM, iaitu sekitar tahun 1920-an sehingga pertengahan 1930-an, dipercayai gerakan antipenjajahan di Tanah Melayu disusun, digerak dan dikendalikan sepenuhnya oleh orang luar, terutama dari Indonesia. Malah selepas penubuhan KMM, dipercayai nasionalis-nasionalis Melayu radikal - terutama ahliahli KMM - didedahkan dengan ideologi politik Sosialis Marxisme yang dibawa oleh Tan Malaka, Alimin, Sutan Djenain, Musso, Djamaluddin Tamim, Soebakat, Semaun, Mohamed Ariff dan lain-lain lagi dari PKI. Perkembangan ini diteruskan dalam pertubuhan-pertubuhan seperti PKMM dan API (al-Juneid 2015, 54). Malah Tan Malaka dipercayai telah berada di Semenanjung Tanah Melayu sebanyak empat kali, iaitu sekitar tahun 1925 sehingga 1926 (Singapura dan Pulau Pinang), 1937 (Singapura), 1939 sehingga 1942 (Singapura) dan 1942 (Pulau Pinang) (Tan Malaka 1948). Tan Malaka bersama-sama sahabatnya yang bernama Ahmad Zubir 
(bekas ahli PKI) dan Ariffin (Presiden Singapore Free Trade Union cawangan Kelantan dan bekas ahli PKI) telah melarikan diri ke Singapura dan Tanah Melayu sekitar November tahun 1925, setahun sebelum peristiwa pemberontakan PKI di Indonesia (CO 537/3752; FCO 141/15672).

Pengaruh personaliti memainkan peranan besar dalam perkembangan ideologi sosialis di Tanah Melayu (CO 537/2177; CO 537/7294). Pemikiran Tan Malaka dan Alimin, khususnya, merupakan antara watak nasionalis Indonesia yang banyak mempengaruhi gaya pemikiran politik aliran kiri atau radikal Melayu pada waktu itu. Dalam hal ini, ia berkait rapat dengan fungsi yang digerakkan oleh Tan Malaka dan Alimin melalui pemikiran mereka dalam mengembangkan ideologi nasionalis berteraskan fahaman Sosialis Marxisme. Perkembangan ini berlaku melalui kuliah-kuliah politik yang diadakan secara tertutup kepada orang Melayu di Tanah Melayu dan Singapura untuk menarik sokongan mereka mendukung ideologi Marxisme. Di samping itu, ia juga bertujuan untuk menyemai semangat antipenjajahan terhadap British melalui kegiatan penulisan sama ada dalam bentuk artikel atau risalah yang ditulis oleh nasionalis-nasionalis Sosialis Marxisme dari Indonesia. Sentimen antipenjajahan turut berkembang di negerinegeri utara Tanah Melayu melalui peranan bekas ahli-ahli PKI. Pada Julai 1926, pelarian PKI yang bernama Sutan Pepateh dilaporkan berada di Kedah dan utara Perak untuk mengembangkan fahaman komunisme dan idealisme antipenjajahan (CO 537/3752; FCO 141/15672). Pada pertengahan tahun 1928 di Singapura, perkembangan tersebut dibawa oleh Alimin melalui peranannya dalam penubuhan cawangan The League Against Imperialism and Colonisation and for National Liberties (CO 537/3752; FCO 141/15672).

Pada tahun 1929, perkembangan ini terus berlanjutan ke Negeri Sembilan dan Melaka melalui penubuhan Kaum Bahru Laut (The New Sea Party) dan Kaum Muda (Youth Movement) yang berfungsi menyemai semangat antipenjajahan berteraskan fahaman Sosialis Marxisme (CO 537/3752; FCO 141/15672). Kesannya, sekitar Oktober tahun 1930 sehingga Februari 1931, penyertaan orang Melayu dalam PKM semakin meningkat, terutama di daerah-daerah yang berteraskan aktiviti pertanian seperti di Kuala Pilah, Rembau dan Melaka yang dipercayai keahliannya di antara 400 hingga 500 ahli (namun perkembangan tersebut berjaya disekat pihak polis pada Mac 1932) (CO 537/3752; FCO 141/15672). Pada peringkat ini, tumpuan perkembangan Sosialis Marxisme lebih terarah kepada orang Melayu di kawasan pinggir bandar dalam kalangan buruh dan petani. Selain Negeri Sembilan, Melaka dan negeri-negeri utara Tanah Melayu, perkembangan ini dapat dilihat juga di Terengganu. 
Penubuhan Parti Seluruh Melayu (All-Malay Party) pada Mei 1932 telah memberi ruang pendedahan kepada orang Melayu untuk terlibat dalam gerakan politik. Parti yang diasaskan oleh individu yang bernama Bassa (bekas ahli PKI), atau juga dikenali sebagai Abdul Rahman Wadoed, dilihat juga sebagai parti politik terawal di Tanah Melayu yang memberi perhatian kepada penyertaan orang Melayu sahaja. Parti ini tidak dipengaruhi oleh orang Cina dan dilihat mempunyai persamaan ideologi dengan Parti Republik Indonesia (PARI) yang diasaskan oleh Tan Malaka dalam menyuburkan pemikiran politik Melayu. Hal ini jelas dapat dilihat melalui peranan beberapa 'orang kanan' Tan Malaka dari PARI seperti Djamaluddin Tamin, Emed@Abdul Hamid, Abdul Rahman@Bahruddin, Mohamed Saad@Mansor, Sardjono, Senawi dan Zubir yang bergerak aktif dalam Parti Seluruh Melayu. Mereka ini juga merupakan bekas ahli PKI yang melarikan diri sebelum ini ke kepulauan Borneo, Singapura dan Tanah Melayu. Berdasarkan risikan British, Parti Seluruh Melayu bergerak di beberapa negeri bermula dari kepulauan Borneo, Pahang, Selangor, Perak, Terengganu dan Singapura (CO 537/3752; FCO 141/15672). Melalui Parti Seluruh Melayu, orang Melayu didedahkan dengan doktrin nasionalisme ekstrem dalam kegiatan politik mereka. Malah penubuhan Parti Seluruh Melayu ini kebetulan ada kaitannya dengan surat yang pernah ditulis oleh Tan Malaka sekitar November 1925 kepada sahabatnya di Indonesia tentang kedudukan orang Melayu tujuh tahun sebelum penubuhannya dalam menggambarkan keadaan sosiopolitik di Tanah Melayu dan Singapura:

So far not the slightest advantage is to be seen from the work of our
dealers (propagandists) at (Singapore) or at (Penang). You may say that
they are quite incapable, but in criticising it must not be forgotten that
the proper (indigenous) inhabitants there, who form only a minority, are
all conservative in their manner of living and thinking and are pretty
burgeois. On the departure of Hadji Moek from (Singapore) his kindness
was invoked to make a visit to F.M.S. The impression which he obtained
everywhere did not differ from those gained from (Singapore) and
(Penang). The section of the people which understand (economy) and
(politics) are the (Chinese). In the harbours, in building, in the trains,
and above all in commerce, the (Chinese) are the most prominent. None
the less their Federation is very weak. (CO 537/3752; FCO 141/15672)

Di samping itu, pengaruh Sosialis Marxisme juga berkembang melalui kegiatan penulisan. Pada tahun 1931, Kesatuan Buruh di bawah pengaruh Alimin telah menerbitkan risalah berkala, Soaera Boeroh Malaya, dalam bahasa Melayu dan Jawa yang dilaporkan telah diterbitkan di Terengganu (CO 537/3752; FCO 141/15672). Kesatuan Buruh ini juga mempunyai hubungan secara langsung dengan Kaum Bahru Laut dan Kaum Muda. Malah Soaera Boeroh Malaya juga dikenali sebagai ejen media propaganda komunis kepada orang Melayu dan India. 
Melalui artikel yang ditulis oleh Alimin, terutama yang berkaitan dokumen Red Labour, usaha menarik sokongan penduduk di Tanah Melayu dan Indonesia untuk berpihak kepada komunis giat dijalankan. Perkembangan ini secara tidak langsung mengesahkan laporan yang dikeluarkan oleh perisik Belanda terhadap PKI, iaitu "Plan of the Work of the D.E.I.B." (Dutch East Indies Bureau) yang menyatakan, "to assist in all possible ways similar work done by the C.P.M. [Communist Party of Malaya] in establishing our movement amongst the Malay races" (CO 537/3752; FCO 141/15672).

Sementara itu, di Kaherah, Mesir, Alimin dan Musso turut menggunakan akhbar Pilihan Timor dan Seruan Azhar untuk mempengaruhi pelajar-pelajar Tanah Melayu yang menuntut atau menetap di sana. Kedua-dua akhbar tersebut mempunyai kaitan dengan gerakan Islah di Timur Tengah. Dalam konteks ini, ia membuktikan bahawa pernah adanya satu bentuk kerjasama secara tidak rasmi antara gerakan Islah di Timur Tengah dengan pendukung Sosialis Marxisme, sepertimana yang pernah dilakukan oleh PKI dan Sarekat Islam sekitar tahun 1915 sehingga 1921. Hal ini berdasarkan sumber British yang menyebut:

The League against Imperialism which had on listed the aid of Alimin and Moeso, attempted to get in touch with the young intelligentsia of the N.E.I. and Malays studying at the Al-Azhar University, and apparently had some measure of success. (CO 537/3752; FCO 141/15672)

Malah kandungan dalam artikel Pilihan Timor menyeru penduduk di Tanah Melayu menentang kuasa penjajah dengan menjadikan perjuangan Mesir dan China sebagai panduan:

Malays of the Peninsula, do you willingly allow your country to be governed by a nation which is for ever greedy? Have you never thought of gaining your freedom? Look at Egypt and China; what race governs these countries? Let us follow the example of our brethren in Java and Sumatra ... The Japanese are also an Asiatic race, a coloured much like ourselves. How is it that they are able to stand on their own and not to be dominated by another race? ... Let us find ways and means to work out the freedom of our country from the domination of greedy races. (CO 537/3752; FCO 141/15672)

Peranan bekas ahli-ahli PKI dalam mengembangkan fahaman Sosialis Marxisme di Tanah Melayu dan Singapura juga ada kaitannya dengan arahan yang dikeluarkan oleh Jawatankuasa Pusat Parti Komunis China (PKC) kepada pemimpinpemimpin kanan PKM yang berbangsa Melayu. Pada September 1933, PKC telah mengirimkan surat arahan kepada PKM yang jelas menyatakan butiran berikut: 
We must realise that it is the proletarians and their allies-the peasantswho can carry out from beginning to end the anti-Imperialist movement and the agrarian revolution which, under the leadership of the proletariat and the Bolshevik Party, will the end lead to the socialist revolution. In the progress of the anti-Imperialist campaign and the agrarian revolution, Malaya is a field for both. Due to geographical proximity, Malaya, as the vanguard of the colonial and semi-colonial revolution, has very intimate connection with China's revolutionary movement. Our mission is, therefore, to lead the Malayan native peasants and labourers to join the revolutionary movement, which without them, will not be a success. (CO 537/3752; FCO 141/15672)

Surat ini membuktikan kepentingan kedudukan Tanah Melayu dan orang Melayu dalam gerakan revolusi Sosialis Marxisme untuk memperkukuhkan kuasa komunis di rantau ini. Sehubungan itu, peranan Sutan Djenain dilihat penting dan beliau dipertanggungjawabkan untuk menyusun gerakan menarik sokongan orang Melayu terhadap PKM. Pada tahun 1935, Malayan Racial Emancipation League diwujudkan di bawah kelolaan Sutan Djenain yang berfungsi sebagai unit propaganda untuk menarik sokongan dan penyertaan orang Melayu dan India menyertai PKM. Turut sama membantu Sutan Djenain adalah rakan-rakannya dalam PKI seperti Budiman @ Sajoeti, Salim, Amir Hamzah Siregar dan Djeliman Siregar (CO 537/3752; FCO 141/15672).

\section{Perbezaan Sudut Pandang Sosialis Marxisme Alimin dan Tan Malaka}

Secara dasarnya, pemberontakan PKI pada tahun 1926 di Banten dan Sumatera Barat tidak dipersetujui oleh Tan Malaka (McVey 1965, 316-322). Malah Tan Malaka dilabelkan sebagai pengkhianat PKI oleh rakan-rakanya seperti Alimin, Semaun, Musso dan Darsono. Alimin melihat pemikiran Tan Malaka tidak mewakili pemikiran komunis yang autentik berpandukan kepada Marx dan Engels, tetapi lebih kepada pemikiran Trotskyist. Kritikan Alimin terhadap Tan Malaka telah tersebar melalui artikelnya yang bertajuk Analysis - Alimin versus Tan Malaka. Artikel tersebut dihasilkan sebagai tindak balas Alimin terhadap tulisan Tan Malaka sebelumnya yang bertajuk Thesis. ${ }^{3}$ Dalam isi kandungan artikel tersebut, Alimin menegaskan bahawa perjuangan Tan Malaka telah tersasar daripada prinsip asas parti komunis yang berpusatkan kepada idealisme Lenin dan Stalin dan menempatkan dirinya di luar dimensi internasionalisme. Tan Malaka menekankan kematangan berbeza dalam gerakan dan revolusi politik yang perlu bermula dari dalaman dan bersifat nasional (FCO 141/15672; Poeze 1999, 415417). 
Perbezaan idea politik antara Alimin dengan Tan Malaka menampakkan sisi sebenar dalam kerangka perkembangan sosialis di Tanah Melayu. Berdasarkan rekod British, telah diadakan sesi diskusi ilmiah yang turut dihadiri oleh ahli-ahli PKM, PKMM, PETA dan bekas ahli-ahli API dalam membincangkan sebuah buku yang bertajuk Bong Alimin dan Tan Malaka. Sesi diskusi tersebut diadakan di kediaman Kamarulzaman Teh (bekas ahli jawatankuasa API dan ahli PKMM) di Pahang yang juga berfungsi sebagai Balai Pustaka Tanah Ayer Melayu, yang dipercayai British sebagai institusi penerbitan buku propaganda komunis. Turut serta dalam sesi diskusi ilmiah tersebut adalah Abdul Rashid Maidin (ahli jawatankuasa PKM dan bekas ahli jawatankuasa API), Abdullah C.D. (ahli jawatankuasa PKM, PKMM dan bekas ahli API), Samsuddin Salleh (ahli jawatankuasa PKM dan editor majalah Pelupor) dan Atom Mun (Bendahari PETA Pusat dan bekas ahli API) (FCO 141/15673). Perbincangan ini merupakan satu bentuk diskusi ilmu politik dalam melihat perbezaan fahaman Marxisme antara Alimin dengan Tan Malaka. Secara tidak langsung, dalam konteks gerakan revolusioner di Tanah Melayu perselisihan idealisme politik antara kedua-dua tokoh terbabit memberi kesan terhadap bentuk perkembangannya dalam kalangan aktor nasionalis tempatan.

Alimin dan sahabatnya Musso dilihat sebagai pendukung aliran MarxismeLeninisme; manakala Tan Malaka sebaliknya berbeza dan tidak terikat dengan pegangan fundamental gerakan komunis. Keputusan dan pendekatan politik Alimin masih di bawah dasar induk Communist International (Comintern). Hal ini jelas dibuktikan melalui hubungan Alimin dengan Comintern sekitar tahun 1929 sehingga 1930. Comintern ketika itu di bawah kepimpinan China berbanding sebelumnya dipimpin oleh Soviet Union (CO 273/535/1). Segala keputusan dan dasar parti-parti komunis di Asia Tenggara dikawal selia oleh Far Eastern Bureau of the Comintern yang berpusat di Shanghai (Cheah 1992, 15). Pada waktu itu, Comintern dipimpin oleh Nguyen Ai Quoc atau lebih dikenali sebagai Ho Chin Minh. Peranan Nguyen Ai Qoc cukup besar dalam menyusun strategi dan pendekatan politik bagi menarik perhatian orang Melayu menyertai PKM.

Nguen Ai Quoc, who at the third Representative Conference of the M.C.P. had urged particularly the need for Chinese members to study the Malay language and enlist Malay recruits, was extremely active in the development of the Malay and Javanese Party. (CO 537/3752; FCO $141 / 15672)$

Seterusnya,

The development of nationalism and awakening to political consciousness among Malays was apparent. It was realised that such a 
movement would certainly receive the sympathetic attention not only of the local Commmunist Party but also of those political agitators of the Netherlands East Indies who, having fled their country after 1926 rising, were still available to carry out the "racial" movement in the South East Asian which was the declared policy of the Third International. (FCO 141/15672)

Di samping itu, idea doktrin nasionalisme ekstrem dalam kalangan orang Melayu dikembangkan oleh Alimin dan sahabat-sahabatnya melalui Anti-Imperialism League yang membawa impak kepada pemikiran radikal dan sentimen revolusi dalam gerakan nasionalisme Melayu pada penghujung tahun 1940-an (CO 537/3752; FCO 141/15672). Alimin menekankan intipati internasionalisme dalam mewujudkan jaringan komunisme yang meluas dengan menjadikan Soviet Union dan China sebagai induk hubungan tersebut. Melalui gerakan buruh antarabangsa yang dipengaruhi oleh Comintern dan penglibatannya dalam Pan-Pacific Labour Conference, aktiviti propaganda semakin hebat di Tanah Melayu di bawah Alimin dan beberapa sahabat baiknya seperti Musso, Sardjono dan lain-lain. Penubuhan organisasi buruh seperti Kesatuan Buruh di Singapura merupakan lanjutan propaganda dan strategi dalam menyebarkan ideologi komunisme dalam kalangan orang Melayu.

We must also know that the young labourers, peasants and some portion of the students will enhance the influence of the party in the midst of the revolutionary struggles. Consequently, the development of the Communist Youth is also one of our important duties. Activities of the Red Labour Union are also very important ones. The work should not be done by a few monrades only sent by us; you must train all your members to take part in it as a powerful organisation. We must act in such a manner that we will make the Labour Union become an all-powerful organisation in the making struggle. (CO 537/3752; FCO 141/15672)

Walau bagaimanapun, hal ini berbeza dengan Tan Malaka. Kerangka pemikiran politik Tan Malaka bersumberkan tiga elemen asas, iaitu sosialisme, Islam dan bangsa Melayu. ${ }^{4}$ Semasa persidangan Comintern kali ke-4 di Moscow pada 22 November 1922, Tan Malaka menjelaskan perlunya penggembelengan secara berterusan untuk menyatupadukan gerakan Islam dengan sosialis dalam usaha menyingkirkan penjajah dan memerangi fahaman kapitalis. Bermula dari situ, pandangan Tan Malaka terhadap komunis mula berubah dan tidak terikat dengan dasar Comintern. Pandangan Tan Malaka ini sekali gus menolak tesis yang dikemukakan oleh Lenin semasa sidang Comintern kali ke-2 di Moscow dan Petrograd pada Julai 1920 yang menekankan perlunya perjuangan melawan Pan-Islamisme. Pandangan Tan Malaka dalam persidangan tersebut berkait rapat 
dengan pengalamannya dalam menjalinkan kerjasama antara PKI dengan Sarekat Islam. Kerjasama tersebut dilihat begitu berpengaruh di Indonesia sekitar awal tahun 1920-an sehinggakan dalam pidatonya, Tan Malaka menjelaskan:

Pan-Islamisme punya sejarah panjang. Pertama saya ingin bercerita tentang pengalaman kami bekerjasama dengan kelompok Muslim di Hindia. Di Jawa kami memiliki sebuah organisasi beranggotakan buruh-buruh miskin, Sarekat Islam, yang pada 1912-1916 memiliki satu juta anggota ... mungkin juga tiga atau empat juta. Ini sebuah gerakan revolusioner yang amat besar dan muncul secara spontan. Kami bekerjasama dengan kelompok ini sampai 1921. Sekitar 13 ribu anggota kami bergabung dan melakukan propaganda di dalam. Pada 1921 itu kami berhasil mempengaruhi mereka menjalankan program kami. Perkumpulan Islam itu mendorong masyarakat desa mengambil alih kendali perusahaan-perusahaan. Semboyannya: petani miskin menguasai semuanya, proletar menguasai segalanya! Jadi SI telah melakukan propaganda yang sama dengan Partai Komunis, cuma kadang kala dengan nama lain. ${ }^{5}$

Tan Malaka dilihat tidak jumud dalam satu aliran dan bersikap kritis dalam memahami Marxisme. Beliau bersikap analitikal dalam menangani gerakan nasionalisme dan antipenjajahan. Dalam erti kata lain, Tan Malaka melihat kerangka nilai-nilai tempatan yang positif mampu menjanakan sifat revolusioner dalam gerakan nasionalisme. Pengalaman beliau di luar Indonesia sejak tahun 1925 sehingga 1942 menjadikan struktur pemikiran politiknya lebih terbuka dan tidak begitu terikat dengan Marxisme sepenuhnya. Beliau mengambil contoh perjuangan Dr. Sun Yat Sen (China) dan Jose Rizal (Filipina) dalam memperjuangkan hak rakyat negaranya dan memuji pendekatan kedua-dua nasionalis tersebut. Dalam hal ini, Ignas Kleden dalam komentarnya terhadap Tan Malaka menyatakan: "Tan Malaka bukanlah seorang Marxis fundamentalis, karena dia dapat menghargai Dr. Sun Yat-sen, nasionalis pengkritik Marxisme, dan mengagumi Dr. Rizal, seorang sinyo borjuis Tagalog, Tionghua dan Melayu" (Siri Buku Tempo Tan Malaka: Bapak Revolusi yang Dilupakan 2015, 142).

Oleh itu, penolakannya terhadap fahaman Lenin dan Stalin dalam konteks amalan politik Indonesia dan serantau Melayu lebih kepada justifikasi kesesuaian dan implementasinya dalam budaya politik tempatan. Menurut Tan Malaka:

Kepimpinan Moskow hanya baik untuk Rusia saja. Dengan contoh-contoh dari Jerman, Italia dan Bulgaria sudah diperagakan bahwa kepimpinan Moskow gagal untuk negeri-negeri lain. Seluruh Internasionale Ketiga dibentuk demi kepentingan Rusia dan khususnya pemimpin-pemimpin 
muda Timur akan cenderung beralih ke pemujaan buta dan kehilangan kemerdekaan mereka dengan akibat mereka akan kehilangan hubungan dengan massa mereka sendiri yang memiliki dorongan kewajipan yang berbeda dengan Rusia. (Jarvis 2000, 29-30)

Melalui fahaman Reformis Marxisme, gagasan politik yang dibawa Tan Malaka bermatlamatkan 'Federasi Repoeblik Indonesia' yang meliputi seluruh rumpun Melayu merangkumi Filipina, kepulauan Borneo, Semenanjung Tanah Melayu dan Indonesia. Ahmat Adam dalam mengulas hal ini menyatakan: "Dalam gagasan Tan Malaka sebuah persatuan seluruh bangsa Indonesia [rumpun Melayu] yang merangkumi Filipina dan Semenanjung Tanah Melayu [termasuk Singapura] tidaklah mustahil. Tujuannya mewujudkan Indonesia Raya itu adalah demi kepentingan strategik negaranya apabila merdeka" (Ahmat Adam 2013, 60).

Tan Malaka dalam tulisannya yang berjudul Aksi Massa, menjelaskan keperluan gabungan dunia Melayu dalam usaha memperkukuhkan daya saing politik dan ekonomi bagi menangani kuasa imperialisme Belanda dan British. Gagasan nasionalisme Tan Malaka adalah satu bentuk kepentingan strategik bagi menyatukan dan memperkukuhkan 'Kesatuan Melayu' yang perlu diterajui oleh masyarakat Indonesia sebagai "pemimpin yang dipertanggungjawabkan" (Tan Malaka 2000, 136-137). Pendirian radikal Tan Malaka terhadap gagasan Kesatuan Melayu ini dilihat sebagai satu langkah awal dalam mewujudkan wilayah Melayu yang merdeka, bebas daripada cengkaman imperialisme dan kawalan bangsabangsa lain. Menurut Tan Malaka (2000, 137):

Celaka sungguh, bangsa Indonesia di Semenanjung Malaka tak dapat mempertahankan diri dari kebanjiran bangsa India dan Tiongkok yang terus mengalir ke sana. Perniagaan industri boleh dikatakan semuanya ada di tangan asing. Bumiputra di kota-kota pesisir senantiasa didesak ke pinggir kota, dan yang tinggal di darat makin hari makin jauh menyingkir ke puncak-puncak gunung.

Sudut pandang Tan Malaka ini merupakan satu idealisme afirmatif berdasarkan pemikiran kelas dalam membangunkan masyarakat Melayu sebagai peribumi gugusan kepulauan Melayu. Perbezaan sudut pandang inilah yang memperincikan idealisme politik antara Alimin dengan Tan Malaka. Walaupun kedua-duanya bermula daripada fahaman komunis berasaskan nilai politik internasionalisme, namun selepas tahun 1922 pendirian Tan Malaka mula cenderung kepada nasionalis Reformis Marxisme yang dilihat 'tidak terikat dengan fahaman Marxisme mutlak'. Alimin pula terus mengekalkan jiwa Sosialis Marxisme yang berpandukan doktrin komunis Leninisme. Namun begitu, persamaan yang boleh diteliti antara keduadua tokoh ini adalah penekanan kepada doktrin nasionalisme ekstremis dalam 
menghadapi kuasa imperialis sama ada Belanda mahupun British dan hegemoni golongan kelas atasan ke atas kelas bawahan.

\section{Interpretasi Sosialis Marxisme dalam Gerakan Radikal Melayu Sekitar Tahun 1940-an}

Perkembangan Sosialis Marxisme di Tanah Melayu dicorakkan dalam dua bentuk kefahaman yang berbeza. Dua bentuk tersebut didasari secara tidak langsung oleh elemen fahaman politik yang dirangka oleh Alimin dan Tan Malaka. Pertama, kefahaman komunis yang cenderung kepada gerakan revolusi dalam kalangan orang Melayu melalui pengaruh bekas ahli-ahli PKI di Tanah Melayu. Kedua, kefahaman Reformis Marxisme melalui kerangka nasionalis berdasarkan pendekatan radikal dalam kalangan orang Melayu. Bentuk pertama ini adalah acuan yang dibawa oleh Alimin, Musso dan seterusnya Sutan Djenain yang banyak mempengaruhi orang Melayu dalam PKM, PKMM, API, PETA dan Barisan Tani (BATAS) sekitar tahun 1940-an. Bentuk kedua pula lebih cenderung kepada idea nasionalis yang dibina Tan Malaka berasaskan perjuangan radikal antikelas dan anti-British dalam kerangka Reformis Marxisme dalam kalangan orang Melayu. Namun begitu, daripada sudut pensejarahan politik idea Tan Malaka sukar untuk dibuktikan pengaruh perkembangannya di Tanah Melayu sekiranya hanya didasari oleh pemahaman langsung daripada risikan sumber-sumber British sahaja, tetapi perlu dikupas secara terperinci melalui tafsiran daripada sumber-sumber British tersebut dan tulisan travelognya yang berjudul Dari Pendjara ke Pendjara. Melalui tulisan tersebut, Tan Malaka mengkritik dengan jelas tahap kemampanan sosiopolitik dalam kalangan orang Melayu di Tanah Melayu pada waktu itu yang agak terbatas pegangan ekonominya, kesan daripada dominasi orang luar. Pada waktu itu, orang Melayu dilihat selesa "dalam kawalan pihak British dan peniagapeniaga bukan Melayu" (Tan Malaka 1948, 100-101). Di sinilah titik kesesuaian Reformis Marxisme yang dibawa oleh pemikiran Tan Malaka dalam konteks latar belakang budaya politik Melayu pada waktu itu.

Situasi ini ada kaitannya dengan kefahaman dan kemampuan orang Melayu pada waktu itu dalam memahami kerangka politik moden dan ideologi perjuangan. Orang Melayu pada waktu itu tidak mempunyai pendedahan yang luas terhadap idealisme aliran-aliran politik melainkan mereka yang mendapat pendidikan di luar negara seperti di Britain dan Timur Tengah. Dalam konteks ini, Ahmad Boestamam mengakui peranan yang digerakkan oleh nasionalis-nasionalis dari Indonesia dalam membantu mengembangkan kefahaman ilmu politik dalam kalangan orang Melayu. Menurut Ahmad Boestamam: 
Kita mengadakan pertemuan, discussion group selama begitulah bertukar-tukar di atas ini, jadi waktu itu ada seorang Indonesia yang kiri dari Indonesia tinggal di Kuala Lumpur ini, bernama Sutan Jenain ... jadi dia [Sutan Djenain] banyak tahu berkenaan dengan socialism, bahkan berkenaan dengan communism juga dia tahu. Apa socialist? Semua ini, jadi kita oranglah selalulah pergi berjumpa dengan dia, menerima kursus berkenaan dengan socialism. Jadi pada ketika itulah baru kita sikit-sikit tahu berkenaan dengan socialist, sebab sebelum itu tahu berkenaan dengan nationalism sahaja, semangat kebangsaan sahaja. (2012/0014419, Transkrip Lisan Wawancara Datuk Ahmad Boestamam)

Kenyataan Ahmad Boestamam mendedahkan beberapa tafsiran dalam menghubungkan kebangkitan nasionalisme dan pendedahan ilmu politik dalam kalangan orang Melayu pada waktu itu. Pertama, kelompok orang Melayu yang terdedah kepada idea nasionalisme berdasarkan kerangka Sosialis Marxisme sekitar tahun 1930-an sehingga awal 1940-an, yang akhirnya meletakkan diri mereka dalam kerangka komunisme sebagai ideologi perjuangannya. Antara pejuang Melayu yang cenderung kepada aliran Sosialis Marxisme berfahaman komunis adalah seperti Abdul Rashid Maidin, Abdullah C.D., Arshad Ashaari (ahli PKM, bekas ahli API), Musa Ahmad (bekas ahli API), Kamarulzaman Teh, Wahi Anuar (bekas ahli jawatankuasa API dan Ketua PETA), Zulkifli Owni (bekas ahli jawatankuasa API dan anggota Tentera Republik Indonesia, TRI), Zahid Karim (Ketua PKMM Negeri Sembilan) dan Shamsiah Fakeh (Ketua AWAS). Kelompok ini yang dikatakan mempunyai hubungan secara langsung dengan gerakan komunis sekitar tahun 1945 sehingga 1948 melalui kesatuan buruh, gerakan pemuda dan sistem pendidikan (sekolah-sekolah Melayu dan Cina) sepertimana yang direkodkan sumber British.

Kelompok ini mendapat pendedahan politik secara langsung daripada Alimin, Musso dan Sutan Djenain serta tertarik dengan idea revolusi (Fujio 2010). Peranan aktor-aktor komunis Indonesia ini diakui oleh Chin Peng, terutama penglibatan Alimin dalam merekrut pemikiran Marxisme komunis dalam kalangan orang Melayu sekitar pertengahan tahun 1940-an (Chin dan Hack 2004, 71-72; Abdullah C.D. 2005, 162). Kegiatan ini diperakui oleh PKM yang jelas menyatakan: "A Malay cadres during of the PKI, comarade Alimin, helped to narute our our party's Malay cadre during the peace period of the early postwar days" (MCP n.d., 38). Melalui Sekolah Marxist di Tanah Melayu, pemikiran Marxisme dikembangkan dan Alimin antara watak terawal yang mendedahkan ideologi tersebut dalam kalangan orang Melayu. Menurut Abdullah C.D., kursus Marxisme tersebut diadakan dalam tempoh dua minggu yang turut disertai oleh bukan ahli-ahli PKM seperti Ahmad Boestamam, Dahari Ali dan Aishah Ghani; malah Aishah Ghani telah mendapat markah tertinggi dalam ujian yang diadakan di sekolah terbabit (Abdullah C.D. 2005, 163). 
Kedua, kelompok yang terdedah kepada idealisme Sosialis Marxisme tetapi tidak cenderung menjadikan fahaman aliran komunisme sebagai asas perjuangan mereka. Kelompok kedua ini merupakan golongan nasionalis Reformis Marxisme yang melihat kepentingan dan kebangkitan budaya politik kelas rendah dan sederhana bersama-sama kelas atasan dalam kalangan orang Melayu bagi membentuk struktur kekuatan Melayu di peringkat asas. Dalam konteks yang lain, kelompok kedua ini cuba memecahkan tradisi elit politik yang selama ini didukung oleh golongan raja dan bangsawan Melayu. Mobilisasi kelompok ini dilihat sebagai suatu proses kemuncak peralihan pembentukan kelas elit politik baharu dalam kalangan kelompok bukan tradisional (Rustam 2004, 38-40). Kelompok ini merombak pandangan Marxisme dalam mengutarakan matlamat perjuangannya. Sepertimana Tan Malaka, kelompok ini memberi perhatian kepada kedudukan orang Melayu dan Islam sebagai teras pembinaan negara. Teras ini yang memandu reka bentuk pemikiran politik sebahagian besar aktor-aktor KMM dan PKMM dalam menjalin kerjasama dengan orang bukan Melayu dan seterusnya mampu mempengaruhi sebahagian besar masyarakat Melayu sekitar pertengahan tahun 1940-an. Menurut Azai Karim (ahli PKMM, API, PETA): "Tapi di waktu itu, kita sudah menyebut 'sosialisme' yang bertujuan untuk mendirikan satu masyarakat 'sosialis' yang memberi keadilan kepada setiap rakyat, bukannya segelintir rakyat, tapi kepada setiap rakyat sesuai dengan perkataan 'sosialis' itu sendiri”' (Azai 1992, 87).

Penyusunan semula Marxisme ini mempengaruhi bentuk dan hala tuju tuju agenda sosialis yang difahami oleh sebahagian besar ahli PKMM pada waktu itu. Walaupun mempunyai pandangan induk yang hampir sama, namun kefahaman kelompok ini meletakkan idealisme Marxisme dalam acuan yang diadunkan bersama nilainilai nasionalisme, demokrasi dan keadilan kelas. Kefahaman baharu ini yang membezakannya dengan perjuangan yang berteraskan aliran komunis. Kelompok ini menerima prinsip-prinsip perjuangan dan fahaman Marxisme dalam gerakan mereka tetapi menolak komunisme sebagai agenda akhirnya. Penyusunan semula inilah yang dimaksudkan sebagai Reformasi Marxisme dalam gerakan radikal Melayu pada waktu itu. Jelas Azai: "Kemungkinan ada unsur-unsur Marxist yang lebih baik kita sebutnya sebagai 'Marxist'. Kemungkinan dia [pejuang-pejuang Indonesia] membawa unsur-unsur itu, sebab di Indonesia di waktu itu, unsurunsur 'Marxist' sedang berkembang" (Azai 1992, 96). Antara nama besar dalam kelompok ini adalah seperti Ibrahim Haji Yaacob (Ketua KMM), Ishak Haji Mohamed (Presiden ke-3 PKMM), Ahmad Boestamam (Ketua API), Dahari Ali (bekas ahli jawatankuasa API), Taha Kalu (bekas Timbalan Presiden ke-3 PKMM), Othman Karim (bekas Penolong Setiausaha Agung API), Taharuddin Ahmad (pemimpin tertinggi Gerakan Angkatan Muda-GERAM dan bekas ahli KMM) dan Abdullah Zawawi (bekas Setiausaha Agung PKMM). 
Pada peringkat awal, penyertaan beberapa aktor penting berfahaman komunis dalam PKMM dan API telah mencetuskan polemik kedua-dua gerakan tersebut. PKMM lebih bersifat sederhana berbanding API yang menekankan pendekatan agresif dan radikal. Pendekatan ini seiring dengan aliran fahaman komunisme yang bersifat bukan-koperatif dan memberi perhatian gerakan bawah tanah secara revolusi berasaskan militan. Dalam usaha menarik penyertaan orang Melayu dalam PKM, PKMM dijadikan sebagai platform awal untuk mencapai hasrat berkenaan. Usaha ini boleh dilihat melalui artikel yang ditulis oleh Abdul Karim Dzafir (ahli PKMM) dalam Suara MNP yang menerangkan tentang kepentingan perubahan dan kewujudan masyarakat yang bersikap antikapitalis di Tanah Melayu. Paling ketara ketika PKMM di bawah pimpinan Mokhtaruddin Losso (Presiden pertama PKMM) yang juga merupakan ejen komunis dari PKI. "Information has been received from more than one source that attempts are being made to organise young Malays into underground militant groups for the purpose of armed revolution" (FCO 141/15672). Persamaan pendekatan ini yang menjadi hujah, sepertimana yang dijelaskan dalam sumber risikan British berikut:

The Malay Nationalist Party has intensified its propaganda and there is little to distinguish between the propaganda of the M.N.P. and that of the Communist Party. The Party is prepared to support any organisation likely to cause dissension or trouble. The whole pattern of their actions and their policies is very similar to that of the Communist Party. (FCO 141/15672)

Dalam tempoh kerjasama tersebut, PKM seakan 'berlembut' dengan PKMM bagi memastikan penyerapan fahaman komunisme berkembang dalam organisasi tersebut yang dianggap satelit bagi PKM. Malah PKMM bersama PKM pernah menenangkan perasaan orang Melayu yang tidak berpuas hati dengan orang Cina sehingga mencetuskan perbalahan antara kaum di Parit, Perak yang berpunca daripada penjualan buah durian. Peristiwa ini berlaku sekitar tahun 1946, selepas pemerintahan transisi 14 hari di bawah Tentera Bintang Tiga yang dinaungi PKM. Menurut Ahmad Boestamam:

PERKEMAM [PKMM] ini yang memberikan peranan penting sekali cuba hendak menenangkan permusuhan kaum itu supaya jangan timbul besar-besaran. Itulah saya kata tadi PERKEMAM [PKMM] dengan Parti Komunis [PKM] pergi ke Parit untuk menenangkan perasaan orang Melayu ..., semua itu usaha kami untuk mengelakkan pergaduhan kaum. (2012/0014419, Transkrip Lisan Wawancara Datuk Ahmad Boestamam)

Usaha ini digerakkan secara bersepadu oleh Abdul Rashid Maidin, Abdullah C.D. dan lain-lain lagi sambil disokong kuat oleh Sutan Djenain. Namun begitu, peranan 
Sutan Djenain mula dipersoalkan pada penghujung tahun 1947 apabila beliau mula dikaitkan dengan Tan Malaka. Sebagai tindak balas, Abdul Rashid Maidin dalam akhbar Utusan Melayu tegas menyatakan, "Sutan Djenain tiada hubungan dengan komunis" (Utusan Melayu 23 Februari 1948). Kenyataan tersebut ada kaitannya dengan polemik antara Alimin dengan Tan Malaka sebelum itu, yang mana dilihat Sutan Djenain lebih mendukung pendirian Tan Malaka: "Since Sutan Djenain is a Trotskiyist communist and a follower of Tan Malaka is not surprising that Abdul Rashid Maidin, who is a Marxist and a follower of Alimin does not acknowledge him as a communist" (FCO 141/15672).

Malah ada dakwaan yang mengatakan Sutan Djenain ialah salah seorang 'orang kanan' Tan Malaka di Tanah Melayu pada waktu itu walaupun tiada bukti yang jelas untuk mengaitkan hubungan tersebut. Berdasarkan memoir yang dirujuk, watak-watak penting PKM pada waktu itu amat menghormati Sutan Djenain dan ini bercanggah dengan kenyataan Abdul Rashid Maidin (Suriani 2006, 89; Abdullah C.D. 2005, 85-86).

Selain itu, Zahid Karim, Ketua PKMM Negeri Sembilan yang juga anggota PKM, menyatakan bahawa kekuatan PKM melebihi kekuatan PKMM. Sebahagian besar operasi PKMM dipercayai dibiayai oleh PKM pada peringkat awal penubuhannya. Tambahan lagi, PKM mempunyai jentera propaganda yang aktif, terlatih, tersusun dan kuat (FCO 141/15672). Walau bagaimanapun, pada masa yang sama, Zahid Karim mengakui dan percaya bahawa gerakan komunis sukar untuk dikembangkan di Tanah Melayu kerana fahaman komunisme aliran Marxisme-Leninisme ini dilihat bersikap anti-Islam sepertimana yang pernah disuarakan oleh Lenin pada sidang Commintern pada tahun 1922. Suasana itu mempengaruhi tindakan dan pandangan politik orang Melayu terhadap gerakan komunis secara umumnya. Zahid Karim dipercayai mendapat latihan politik dan didikan aliran Sosialis Marxisme berfahaman komunis secara langsung daripada Alimin, terutama dalam memahami ideologi perjuangan dan gerakan revolusi bawah tanah (FCO 141/15672). Pandangan Zahid Karim ini secara tidak langsung memberikan satu gambaran bahawa tidak semua orang Melayu yang mendapat pendedahan politik aliran Sosialis Marxisme cenderung kepada gerakan komunis.

Selepas PKMM berjaya diambil alih oleh Dr. Burhanuddin al-Helmy daripada Mokhtaruddin Losso, pengaruh fahaman komunisme mula diseimbangkan oleh kumpulan-kumpulan nasionalis yang lain seperti kelompok progresif Islam dan Melayu Sosialis, walaupun pada masa yang sama wujudnya perancangan untuk menyingkirkan Dr. Burhanuddin al-Helmy daripada jawatannya. Berdasarkan sumber British, Sutan Djenain memainkan peranan penting bersama-sama aktoraktor komunis tempatan dalam menggerakkan usaha penyingkiran tersebut. 
Penyingkiran ini penting untuk memastikan PKMM bergerak dalam kerangka yang diaturkan oleh PKM melalui penguasaan ahli-ahli PKMM yang berfahaman komunis dalam jawatankuasa pusat PKMM. Peristiwa ini dapat dibuktikan melalui mesyuarat jawatankuasa pusat yang diadakan di Kajang pada 25 Februari 1947, yang mana wujudnya percubaan untuk menyusun semula PKMM berdasarkan aturan yang ditentukan oleh PKI (FCO 141/15955). Perancangan ini dipercayai diteruskan semasa Kongres PKMM kali ke-3 pada 28 Disember 1947 di Singapura melalui wakil PKM, Chan Ming Ching. Berdasarkan rekod British, usaha penyingkiran ini merupakan satu bentuk kerjasama tidak langsung antara PKM dengan PKMM bagi memastikan "appealed to the Malays to co-operate with political parties and other races in Malaya to fight against the Federation of Malaya" (FCO 141/15955).

Perancangan PKM tidak terhenti setakat itu. Selain daripada PKMM, beberapa usaha komprehensif dijalankan oleh ejen-ejen komunis dalam API. Selepas pengharaman API pada 17 Julai 1947 di bawah Seksyen 2(f) Ordinan Pertubuhan 1947, perancangan strategik dalam menyusun dan mengembangkan fahaman komunisme dijalankan secara berorganisasi, sistematik dan berterusan (CO 537/2151). Dalam hal ini, peranan beberapa bekas ahli API yang pro-komunis untuk menarik sokongan ahli-ahlinya menyertai PKM atau menyokong PKM diberi perhatian. Pada 7 November 1947, dipercayai Hussein@ Osman (bekas Setiausaha API Cawangan Pahang), yang dikenali sebagai 'orang kanan' Kamarulzaman Teh telah mengadakan satu mesyuarat di Kota Bharu, Kelantan dalam usaha memujuk Hassan Agus (bekas Timbalan Ketua API Cawangan Kelantan) dan bekas ahliahli API di Kelantan untuk menyertai PKM atau menyokong perjuangan PKM (FCO 141/15955). Penubuhan PETA juga dilihat sebagai alternatif strategik dalam meneruskan perancangan gerakan revolusi 'ala-API' tersebut. Namun bezanya, PETA yang dipimpin oleh Wahi Anuar menjadikan fahaman komunisme sebagai kerangka pemangkin semangat nasionalisme.

Dalam satu mesyuarat yang diadakan di ibu pejabat PKMM pada 12 November 1947 - yang dihadiri oleh Wahi Anuar dan Ahmad Boestamam - menjelaskan titik perbezaan pandangan sosialisme dan agenda perjuangan nasionalisme di antara mereka. Dalam mesyuarat tersebut, Wahi Anuar menyatakan pandangannya bahawa PETA adalah kesinambungan platform gerakan anti penjajahan dalam kalangan bekas ahli API. Menurut Wahi Anuar:

You must have come to know of the basic aims of PETA and the reason why it has been founded in Malays. The object of PETA is none other than to restore the status ex-API members who, we believe, since the banning of API, have been upset and do not know where they stand 
in their struggle. The 10,000 API members are confident that the independence of Malaya depends on them. The birth of PETA, we hope, will be heartily and warmly received by the entire rank and file of API and, more particularly, by you yourself. (FCO 141/15955)

Ahmad Boestamam pula membalasnya seperti berikut:

API has been banned in Malaya. It has an independent ideology. It refused to depend on other opinions. ... I have very favourable views of PETA, but API is only able to support it views. It is unable to cooperate so long as PETA interferes or conflicts with API views. You should remember that if PETA turns out to be a plan (this is translation of the word PETA) which would frame Malayan independence, it would receive ready support from API. But if it should be a plan to intensify or fortify colonial rule in Malaya, API would burn PETA. (FCO 141/15955)

Kenyataan Ahmad Boestamam ini mirip dengan pandangan Tan Malaka. Bagi Ahmad Boestamam, gerakan nasionalisme tidak perlu diikat dengan pegangan sesuatu ideologi politik dan perlu berasaskan kerangka Kesatuan Melayu. Dipercayai Tan Malaka telah menghantar lima 'orang kepercayaannya' untuk membantu Ahmad Boestamam mengembangkan pengaruh API di setiap cawangan negeri-negeri di Semenanjung Tanah Melayu (CO 537/2151). Dalam Testament A.P.I., Ahmad Boestamam menjelaskan keperluan memperjuangkan pembebasan daripada penindasan penjajah berbanding penekanan menjayakan sesuatu fahaman politik. Matlamat Ahmad Boestamam mirip sepertimana yang dianjurkan Tan Malaka:

Di negeri-negeri yang merdeka pemuda-pemudanya berjuang untok mejayakan satu-satu fahaman seperti fahaman communist, faham socialist, faham nationalist dan lain-lain mengikut kechenderungan masing-masing. Tetapi dinegeri-negeri terjajah dan saparoh terjajah perjuangan untok menjayakan satu-satu faham itu ada tetapi tetapi jatuh kepada tingkatan perjuangan yang kedua. Sebab-nya di negerinegeri yang merdeka penindasan dari penjajah tidak ada chuma yang ada penindasan politik, ekonomi dan sosial dari pemerentahan bangsa sendiri sahaja. Tetapi di negeri-negeri yang terjajah dan saparoh terjajah penindasan itu banyak tingkat-tingkatnya. ... Yang demikian sifat perjuangan A.P.I ada-lah termasok dalam gulongan sikap perjuangan pemuda-pemuda di negeri-negeri yang terjajah dan saparoh terjajah itu-lah kerana masih bersifat tanah jajahan. (Ahmad Boestamam 1946, 20-21) 
Manakala Wahi Anuar menekankan idea politik revolusi mutlak dengan meminggirkan peranan golongan raja yang dilihat tidak relevan lagi dalam konteks perjuangan antipenjajahan berteraskan nilai internasionalisme. Pandangan ini dapat ditafsirkan melalui tulisannya dalam majalah Kris yang diterjemahkan dalam bahasa Inggeris:

For years Egypt and Indonesia have been under Imperialist control. Their Sultans have had no real power. By an act of most cunning diplomacy the Imperialists have induced the ra'ayat to believe that the Sultans rule them. In actual fact the Sultans have been used as more tools of the Imperialists against the people ... Malaya is a country under the control of the Imperialists and the Sultans are more puppets. Is this state of affairs satisfactory when the people are in dire poverty, while the Sultan and high officials, like Dato Onn, are enjoying the riches given to them by the imperialists? (FCO 141/15955)

Di sinilah yang meletakkan perbezaan pemikiran politik sosialis yang dipraktiskan oleh Ahmad Boestamam yang cenderung kepada bentuk Reformis Marxisme dan Wahi Anuar yang lebih dilihat dipengaruhi oleh Marxisme-Leninisme (Komunisme). Malah dalam mesyuarat tersebut Ahmad Boestamam jelas tidak bersetuju dengan pendekatan Wahi Anuar dalam PETA, terutama penyerapan pengaruh komunis dalam organisasi tersebut. Dipercayai Ahmad Boestamam pernah membuat satu ketetapan sulit bersama bekas ahli-ahli API dan PKMM yang lain di Kelantan yang diketuai oleh Hassan Agus untuk menyekat perkembangan pengaruh komunis dan penguasaan orang Cina di Tanah Melayu: "Members of MNP and ex API members must fight the Chinese if the Communist interfere with the Malays" (FCO 141/15673). Sumber yang sama juga ada merekodkan kenyataan berikut:

A careful study of their activities and statements indicates that although they repeatedly declare that they are a Nationalist Party, they are anti Government and not opposed to the Communist Party. In addition to the strong Indonesian influences in the Malay Nationalist Party there are still Communist influence. (FCO 141/15673)

Situasi ini memberi kesedaran kepada Ishak Haji Mohamed, Dr. Burhanuddin al-Helmy dan Ahmad Boestamam tentang penyerapan masuk pengaruh komunis dalam PKMM dan API pada waktu itu yang perlu ditangani secara berhikmah dan sistematik.

Kegiatan radikal Melayu sekitar tahun 1947 sehingga 1948 dilihat sebagai satu bentuk 'permulaan dan juga kemuncak gagasan ekstremisme nasionalisme Melayu'. 
Namun begitu ada beberapa pandangan yang melihat gerakan nasionalisme dan antipenjajahan dalam kalangan aktor Melayu radikal ketika itu 'tidak berwatak' atau lebih dipengaruhi oleh sentimen ideologi luar, khususnya propaganda dari Indonesia berbanding membina karaktor perjuangan tempatan. Pandangan ini berdasarkan kata pengantar yang ditulis oleh A. Samad Ismail dalam Memoir Ahmad Boestamam: Merdeka dengan Darah dalam Api seperti berikut:

\begin{abstract}
Teori perjuangan juga dipinjam dari sumber lain sedangkan teori yang paling diperlukan untuk meningkatkan perjuangan ialah teori yang dirumuskan dari tradisi, sejarah dan budaya masyarakat. Peringkat perjuangan ketika itu masih berlegar di tahap agitasi dan propaganda. Ia masih belum meningkat kepada tahap dimana dirumuskan programprogram yang memperincikan garis-garis menebus kemunduran dan kedaifan rakyat dalam bidang politik, ekonomi, budaya dan sosial. Yang demikian tidak hairan kalau sekiranya slogan-slogan berperanan penting dalam membangkitkan kesedaran rakyat dan sebaliknya bukan program pendidikan politik untuk membuka minda pengikut serta mempertajamkan daya pemikirannya. (Ahmad Boestamam 2004, 34)
\end{abstract}

Hujah ini berdasarkan penglibatan A. Samad Ismail dalam PKMM melalui kuliahkuliah politiknya (A. Samad Ismail bukan ahli PKMM tetapi beliau dijemput untuk memberi kuliah politik kepada ahli-ahli PKMM di Singapura, GERAM dan AntiBritish League) di Singapura yang lebih memperlihatkan dominasi orang bukan Melayu, terutama aktivis Malayan Democratic Unit yang sebahagian besarnya adalah pendukung aliran pemikiran politik Sosialis Marxisme seperti John Eber, Lim Hong Bee dan Lim Kean Chye (Howe 1993, 214-219). Persekitaran ini yang membentuk pandangannya (A. Samad Ismail) terhadap gerakan nasionalisme Melayu radikal sama ada mereka yang terlibat dalam PKMM atau API. Walau bagaimanapun, pandangan A. Samad Ismail ini dilihat sebagai satu interpretasi dan persepsi terhadap gerakan politik Melayu khususnya di Singapura, tetapi tidak dilihat secara kolektif di kawasan-kawasan lain di Tanah Melayu. Hal ini jelas dapat dilihat melalui gerakan antipenjajahan di negeri-negeri Melayu utara seperti Perlis dan Kedah melalui Barisan Pemberontak Kita (BAPAK) yang dipercayai ditubuhkan pada 1 Januari 1948 di Alor Setar, Kedah. BAPAK ditubuhkan oleh bekas ahli-ahli API dan PKMM yang bertujuan untuk membangkitkan semangat antipenjajahan dan memupuk nilai nasionalisme radikal berdasarkan kerangka politik yang pernah didukung oleh API sebelumnya (FCO 141/15673). Melalui BAPAK, beberapa siri demonstrasi dan risalah politik tersebar di Perlis dan Kedah. Berdasarkan sumber British, beberapa risalah dan artikel ditemui di negeri-negeri Melayu utara tersebut dalam usaha menarik sokongan orang Melayu menentang penjajahan British. Antara tajuk risalah tersebut adalah seperti: "Pemberontakan bersenjata terhadap Persekutuan British", "Lawanlah Persekutuan dengan titisan 
darah terakhir", "Ayuh semua, bersiap siaga sekarang", "Jangan tunggu janji British: Mereka adalah pendusta", "Kemerdekaan tidak akan diberikan - Ia mesti dirampas" dan "Kemerdekaan tidak perlu dirayu, ia mesti diperolehi dengan pemberontakan" (FCO 141/15673).

Ternyata pembangunan politik Melayu mula berkembang luas sekitar tahun 1940an, terutama selepas era pendudukan Jepun di Tanah Melayu. Dalam konteks ini, interpretasi Marxisme mula dapat difahami dan dikaitkan secara langsung dengan elemen nasionalisme yang dibina pada waktu itu. Orang Melayu mula berani dalam mempersoalkan penyelewangan fahaman tradisi yang lebih mengangkat kelompok elit tradisi, terutama golongan raja dan bangsawan. Secara tidak langsung, isu gerakan antipenjajahan bukan hanya berkisar kepada penjajahan British di Tanah Melayu, tetapi turut menyentuh penyelewengan amalan feudal yang dipraktiskan masyarakat Melayu selama ini. Perubahan dan pembangunan politik Melayu ini ada kaitannya dengan peranan Sekolah Rakyat yang diperkenalkan oleh PKMM sekitar tahun 1946. Sekolah Rakyat dilihat sebagai ejen dalam merekrut dan mendedahkan ahli-ahli PKMM, API dan PETA terhadap budaya intelektual, politik praktis, nasionalisme dan aliran sosialis di Tanah Melayu. Dipercayai idea penubuhan Sekolah Rakyat diambil daripada idea Tan Malaka yang menubuhkan Sekolah Rakyat di beberapa daerah Semarang, Bandung, Medan dan Pulau Jawa di Indonesia sekitar awal tahun 1920-an. Berdasarkan rekod British, Sekolah Rakyat dipercayai wujud di beberapa buah daerah di seluruh Tanah Melayu seperti di Kelantan, Terengganu, Pahang, Johor, Kedah, Negeri Sembilan, Melaka dan Perak. Di daerah Muar, Johor khususnya, Sekolah Rakyat diselaraskan oleh Paiman Adam (ahli PKMM) yang juga bertindak sebagai tenaga pengajar di sekolah tersebut (FCO 141/15672).

Pada 14 November 1947, Sekolah Rakyat semakin berkembang yang mana ia turut disertai oleh anggota-anggota Majlis Tertinggi Agama Islam (MATA) di Gunung Semanggol, Perak. Malah MATA telah menubuhkan Pusat Pentadbiran Sekolah Rakyat (Central Administration of People's Schools) di Gunung Semanggol dalam usaha menyelaraskan operasi Sekolah Rakyat di seluruh Tanah Melayu (FCO 141/15955). Perkembangan ini menunjukkan pembangunan politik Melayu mula bergerak ke arah pembinaan politik moden yang lebih tersusun, sekali gus menafikan kenyataan A. Samad Ismail tentang sikap dan nilai pemikiran politik Melayu radikal pada waktu itu. Tambahan lagi, penubuhan AMCJA dan PUTERA merupakan manifestasi perubahan politik moden hasil daripada produk idea 'lulusan Sekolah Rakyat'. Kerjasama PUTERA-AMCJA dilihat membentuk pakatan politik terawal yang dibina dengan merangkumkan pelbagai aliran politik seperti Sosialis Marxisme, Reformis Marxisme, komunisme dan nasionalis Melayu-Islam serta kaum yang melibatkan kaum Melayu, Cina, India dan Eurasian. 


\section{Kesimpulan}

Sepanjang tahun 1920-an sehingga 1940-an, perkembangan gerakan nasionalisme dan pembangunan politik di Tanah Melayu dipengaruhi oleh pelbagai aliran. Salah satu aliran yang menggerakkan evolusi nasionalisme di Tanah Melayu ialah aliran sosialis, sama ada yang berbentuk Sosialis Marxisme atau Reformis Marxisme. Namun begitu, kecenderungan untuk menyatakan keterikatan kelompok radikal Melayu terhadap fahaman komunisme hanya terbatas kepada kelompok yang menyertai perjuangan PKM atau organisasi-organisasi yang bersekutu dengannya seperti PETA dan BATAS yang menekankan nilai nasionalis internasionalisme. Malah kelompok ini mempunyai jaringan strategik dengan beberapa aktor komunis dari Indonesia seperti Alimin dan Sutan Djenain, terutama pada peringkat awal penubuhan PKMM dan API. Ternyata hal ini berbeza dengan kelompok Reformis Marxisme yang menekankan nilai perjuangan kelas bersifat Kesatuan Melayu dan menampilkan idea-idea politik tempatan, walaupun serba sedikit dipengaruhi oleh pemikiran politik Indonesia, khususnya daripada gagasan politik Tan Malaka. Tidak dinafikan pada peringkat awal, aktor-aktor nasionalis tempatan seperti Ahmad Boestamam, khususnya, didedahkan dengan aliran Marxisme, namun sepertimana Tan Malaka, penyusunan semula Marxisme itu berlaku dalam perjuangan politiknya. Persekitaran ini secara tidak langsung menggambarkan bahawa sejarah gerakan nasionalisme Melayu radikal di Tanah Melayu juga turut dibangunkan oleh elemen aliran sosialis dalam pembangunan pemikiran politik Melayu.

\section{Nota}

1. Sosialis Marxisme merujuk kepada aliran sosialis yang cenderung kepada pemikiran Karl Marx dan Frederich Engel yang lebih radikal dalam memahami kedudukan masyarakat. Aliran ini mempunyai beberapa pecahan, antaranya Marxisme-Kautsky, Marxisme-Leninisme, Marxisme-Moa dan Marxisme-Trotkyist. Dalam konteks Sosialis Marxisme, Marxisme tidak sama dengan Komunisme secara khususnya. Komunisme juga disebut sebagai 'komunisme internasional' yang merujuk kepada gerakan kaum komunis. Komunisme adalah gerakan dan kekuatan politik yang tercetus sejak Revolusi Bolshevik pada Oktober 1917 di bawah pimpinan Lenin (Magnis-Suseno 2000, 5; Howe 1976, 279-285).

2. Reformis Marxisme adalah semakan atau pengubahsuaian (revisionism) Sosialis Marxisme yang berasaskan pemikiran Karl Marx (Landauer 1976, 298-300). Istilah Reformis Marxisme digunakan untuk menggambarkan restructuring yang dibawa oleh Tan Malaka dan pengaruhnya dalam gerakan politik di Tanah Melayu.

3. Dalam Thesis, Tan Malaka (1926) menekankan kepentingan seseorang individu berfikir tanpa dipengaruhi oleh orang lain atau tidak terikat secara mutlak dengan 
sesuatu ideologi. Konsep ini termasuklah daripada sudut menganuti ideologi Marxisme. Seseorang individu tidak harus bertindak sebagai pengikut semata-mata, tetapi perlu menguasai cara berfikir untuk memperoleh hasil kesan yang lebih baik.

4. Gabungan tiga elemen itu yang menampakkan perbezaan pemikiran Tan Malaka yang lebih cenderung kepada sosialis progresif, berbanding pandangan awal umum yang melihatnya lebih menjurus kepada ideologi komunis berdasarkan penglibatannya dalam PKI dan pengaruh dialektik-meterialisme Marx. Walaupun mengagumi pemikiran Troatsky, sehinggakan D.N. Aidit (Ketua Umum PKI) menggelarkannya Trotskyite (lawan kepada pemikiran politik Stalin), tetapi radar kerangka pemikiran Tan Malaka tidak berpusatkan keseluruhannya kepada Troatsky. Persamaan ketara antara mereka ialah kefahaman daripada sudut revolusi dalam mencapai sesuatu matlamat, iaitu perubahan secara menyeluruh. Namun, nilai tambah yang berbeza dalam kerangka pemikiran Tan Malaka ialah sifat sosialnya yang meliputi kesedaran kelas daripada sudut bangsa dan agama. Struktur inilah yang memisahkan pandangan praktis Tan Malaka dengan fahaman komunisme yang didukung oleh PKI.

5. Petikan pidato Tan Malaka semasa Kongres Komunis Antarabangsa di Moscow, Rusia pada 22 November 1922 (lihat Siri Buku Tempo Tan Malaka: Bapak revolusi yang dilupakan 2015, 76). Walau bagaimanapun, terdapat pandangan berbeza dalam hal ini, antaranya tulisan John Ingleson yang menganggap penglibatan anggota PKI dalam Sarekat Islam pada awal tahun 1920-an telah menyebabkan dasar Sarekat Islam tidak jelas dan kekuatan pengaruhnya semakin lemah. Sarekat Islam dalam tempoh itu seakan dikuasai dan ditentukan oleh PKI dalam setiap strateginya. Penguasaan ini boleh dilihat dalam beberapa siri pemogokan di kepulauan Jawa dan Banten pada penghujung tahun 1910-an sehingga awal tahun 1920-an (lihat Ingleson 2014, Chapter II; McVey 1965).

\section{Rujukan}

2012/0014419. Transkrip lisan wawancara Datuk Ahmad Boestamam. Kuala Lumpur: Arkib Negara Malaysia.

Abdullah C.D. 2005. Memoir Abdullah C.D.: Zaman pergerakan sehingga 1948. Petaling Jaya: SIRD.

Ahmad Boestamam. 1946. Testament A.P.I. Kuala Lumpur: L.T.A.P.I. Malaya. . 2004. Memoir Ahmad Boestamam: Merdeka dengan darah dalam api. Bangi: Penerbit Universiti Kebangsaan Malaysia.

Ahmat Adam. 2013. Melayu, nasionalisme radikal dan pembinaan bangsa. Kuala Lumpur: Penerbit Universiti Malaya.

Al-Juneid, S.M.K. 2015. Radical-resistance and protest in colonial Malaya. DeKalb: Northern Illionis University Press.

Azai, K. 1992. Perjuangan nasionalis Melayu Kiri (interview transcript, 3 October). Bangi: Pusat Dokumentasi Sejarah Lisan, Universiti Kebangsaan Malaysia.

Cheah, B.K. 1992. From PKI to the Comintern, 1924-1941: The apprenticeship of the Malayan Communist Party. New York: Cornell Southeast Asia Program. 
Chin, C.C. and Hack, K., eds. 2004. Dialogues with Chin Peng: New light on the Malayan Communist Party. Singapore: Singapore University Press.

CO 273/535/1. Communist activities in Netherlands East Indies: Attempted communist uprising; Alleged connection with Singapore.

CO 273/633. Left Book Club. London: Prohibition of Publication.

CO 537/2151. Angkatan Pemuda Insaf.

CO 537/2177. Indonesia influence in Malaya Peninsula, 1948.

CO 537/3752. Malaya: Political Intelligence Journals.

CO 537/7294. Political developments: Indonesia influence in Malay Peninsula.

FCO 141/15672. 1948. Political Intelligence Journals. Singapore: Malayan Security Service (MSS).

FCO 141/15673. 1948. Political Intelligence Journals. Singapore: Malayan Security Service (MSS).

FCO 141/15955. 1947. Political Intelligence Journals. Singapore: Malayan Security Service (MSS).

FCO 141/15957. 1948. Singapore Local Intelligence Committee Reports. Singapore: Malayan Security Service (MSS) weekly summaries.

Firdaus H.A. 1985. Radical Malay politics: Its origins and early development. Petaling Jaya: Pelanduk Publications.

Fujio, H. 2010. The Malayan Communist Party and the Indonesian Communist Party: Features of co-operation. Journal of Chinese Overseas 6: 216-249, https://doi. org/10.1163/179325410X526113

Howe, I. 1976. Essential works of socialism. New Haven and London: Yale University Press.

Howe, S. 1993. Anticolonialism in British politics, the left and the end of empire, 1918-1964. New York: Oxford University Press, https://doi.org/10.1093/ acprof:oso/9780198204237.001.0001

Ingleson, J. 2014. Workers, unions and politics: Indonesia in the 1920s and 1930s. Leiden: Konnklijke Brill NV, https://doi.org/10.1163/9789004264762

Jarvis, H. 2000. Tan Malaka: Pejuang revolusioner atau murtad? (trans.). Jakarta. Penerbit Cermin.

Kahin, G.M. 1952. Nationalism and revolution in Indonesia. New York: Cornell University Press.

Landauer, C. 1976. European socialism: A history of ideas and movements from the Industrial Revolution to Hitler's seizure of power. Westport, Connecticut: Grreenwood Press Publishers.

Magnis-Suseno, F. 2000. Pemikiran Karl Marx: Dari sosialisme utopis ke perselisihan revisionisme. Jakarta: Penerbit PT Gramedia Pustaka Utama.

MCP (Malaya Communist Party). n.d. Teaching materials of the Malayan Marxism school: Our party's struggle during the peace period soon after the end of the war (mimeograph).

McVey, R.T. 1965. The rise of Indonesian communism. Ithaca: Cornell University Press.

Nabir, A. 1976. Maahad Il-Ihya Assyarif Gunung Semanggol. Kuala Lumpur: Jabatan Sejarah, Universiti Kebangsaan Malaysia. 
Poeze, H.A. 1999. Pergulatan menuju republik Tan Malaka, 1925-1945 (trans.). Jakarta: Pustaka Utama Grafiti.

Roff, W.R. 2003. Nasionalisme Melayu (trans.). Kuala Lumpur: Dewan Bahasa dan Pustaka.

Rustam A.S. 2004. Ke mana nasionalisme Melayu? Kuala Lumpur: R. Publishing Services. . 2011. Asal usul sosial golongan kiri Melayu: Satu analisis berkenaan Kesatuan Melayu Muda. Petaling Jaya: SIRD.

Salleh Lamry, M. 2009. Gerakan kiri Melayu dalam perjuangan kemerdekaan. Bangi: Penerbit Universiti Kebangsaan Malaysia.

Shiraishi, T. 1990. An age in motion: Popular radicalism in Java, 1912-1926. New York: Cornell University Press.

Siri Buku Tempo Tan Malaka: Bapak revolusi yang dilupakan. 2015. Jakarta: Kepustakaan Populer Gramedia dan Majalah Tempo.

Soh, B. 2012. Ideology and shaping of Malaysia: A socio-intellectual history. Jakarta: Penerbit Universiti Indonesia.

Stockwell, A.J. 1979. British policy and Malay politics during the Malayan Union experiment, 1945-1948 (Monograph No. 8). Kuala Lumpur: Malaysian Branch of the Royal Asiatic Society.

Suriani, A. 2006. Memoir Suriani Abdullah: Setengah abad dalam perjuangan. Petaling Jaya: SIRD.

Tan Malaka. 1926. Thesis. Jakarta: Yayasan Massa. 1948. Dari pendjara ke pendjara (Bahagian Kedua). Djogjakarta: Pustaka Murba. 2000. Aksi massa. Jakarta: Teplok Press.

Utusan Melayu. 23 Februari 1948. 